\title{
Effect of electric-current pulses on structural changes in cold rolled copper at different initial temperatures
}

\author{
I. Sh. Valeev ${ }^{\dagger}$, A. Kh. Valeeva \\ †valeevs@mail.ru \\ Institute for Metals Superplasticity Problems of RAS, 39 Khalturina Str., Ufa, 450001, Russia
}

\begin{abstract}
The influence of external current electric fields on the mechanical properties of metals and alloys has been studied for a long time. The effects of electric-current pulses (ECPs) on materials structure were attributed to an increase in the mobility of dislocations in the presence of the electric current (an effect sometimes referred to as "electron wind") and subsequent acceleration of the formation of recrystallization nuclei. At the same time, it has been demonstrated that the Joule heat induced by ECP has some impact on the recrystallization microstructure of the material. What makes the dominant contribution to the structural changes taking place in the material, Joule heating or "electron wind", remains still unclear. The aim of this work was to determine the effect of Joule heating by electric-current pulses on the evolution of grain structure at different initial temperatures in copper specimens. For this purpose, copper samples were rolled to a $90 \%$ thickness reduction and then pulsed at two initial temperatures of the specimens, $20^{\circ} \mathrm{C}$ and $-170^{\circ} \mathrm{C}$, the latter being achieved by cooling with liquid nitrogen. As the integral current densities $0.449 \times 10^{5} \mathrm{~A}^{2} \mathrm{~s} \mathrm{~mm}^{-4}$ for initial room temperature and $1.052 \times 10^{5} \mathrm{~A}^{2} \mathrm{~s} \mathrm{~mm}^{-4}$ for initial temperature $-170^{\circ} \mathrm{C}$ were attained, the material was recrystallized completely. The microstructural changes are compared to similar observations for static recrystallization and explained in terms of Joule heating.
\end{abstract}

Keywords: electric-current pulses, Joule heating, microstructure, electron wind.

УДК 621.3.014.36

\section{Влияние импульсов электрического тока на структурные изменения холоднокатаной меди при разных начальных температурах}

\author{
Валеев И.Ш. ${ }^{\dagger}$ Валеева А. Х. \\ Институт проблем сверхпластичности металлов РАН, ул. Ст. Халтурина, 39, Уфа, 450001, Россия
}

\begin{abstract}
Изучение воздействия внешними электрическими полями на механические свойства металлов и сплавов продолжается в течение длительного времени. Известно, что электроимпульсная обработка (ЭИО) приводит к рекристаллизации, способствует образованию относительно мелкозернистой микроструктуры и замедляет образование двойников отжига. Эти эффекты в меди объяснялись увеличением подвижности дислокаций в присутствии электрического тока (эффект иногда называют «электронный ветер») и последующим ускорением образования зародышей рекристаллизации. Ранее в наших исследованиях наблюдаемые изменения микроструктуры после ЭИО объяснялись Джоулевым тепловыделением при прохождении импульса тока высокой плотности. Вопрос о том, что делает доминирующий вклад в структурные изменения, происходящие в материале, Джоулево тепловыделение или «электронный ветер», по-прежнему остается неясным. Целью этой работы является определение влияния Джоулева тепловыделения при воздействии импульсами тока высокой плотности на эволюцию зеренной структуры при разных начальных температурах в медных образцах. С этой целью медь прокатывали при комнатной температуре до степени деформации $90 \%$, а затем обрабатывали импульсом тока при двух начальных температурах: $20^{\circ} \mathrm{C}$ (комнатная) и $-170^{\circ} \mathrm{C}$, последняя достигалась охлаждением жидким азотом. При достижении интегральной плотности тока $0,449 \times 10^{5} \mathrm{~A}^{2} \mathrm{c} \times \mathrm{Mm}^{-4}$ для начальной комнатной температуры и $1,052 \times 10^{5} \mathrm{~A}^{2} \mathrm{c} \times \mathrm{Mm}^{-4}$ для начальной температуры $-170^{\circ} \mathrm{C}$, в материале происходила полная рекристаллизация. Для сравнения проводили статический отжиг холоднокатаных медных образцов. Происходящие микроструктурные изменения после ЭИО объясняются разогревом образцов в результате Джоулева тепловыделения при прохождении импульса тока.
\end{abstract}

Ключевые слова: импульсы электрического тока, Джоулево тепловыделение, микроструктура, электронный ветер. 


\section{Introduction}

The influence of external current electric fields on mechanical properties of metals and alloys has been studied for a fairly long time [1-6]. It has been demonstrated that an electric field imposed during deformation can enhance the creep rate, decrease the flow stress, reduce strain hardening and increase strain-rate hardening. It can also induce significant microstructural changes.

It was demonstrated that electric-current pulses (ECPs) enhanced recrystallization, promoted the formation of a relatively fine-grained microstructure, reduced the grainboundary cavitation during superplastic deformation and retarded the formation of annealing twins [1-5, 7-13]. These effects were attributed to an increase in the mobility of dislocations in the presence of the electric current (an effect sometimes referred to as "electron wind") and subsequent acceleration of the formation of recrystallization nuclei. The physical mechanism of the "electron wind" is still not completely clear, however. Current theories are based either on an assumption of a specific dislocation resistivity or on quantum mechanics considerations of the interactions between conduction electrons and dislocations $[4,6]$. Influences of ECPs on microstructure, mechanical properties and static recrystallization of the rolled ZK60 magnesium alloy has been studied [14]. The authors report that ECPs rather than Joule heat increased the driving force of recrystallization. In the work [15] crystal rotation in a duplex (austenite + ferrite) steel induced by ECPs at room temperature was observed, while the temperature rising due to Joule heat in the treatment was demonstrated to be negligible.

The "electron wind" hypothesis is not easy to rationalize taking into account that the mass of an electron is $10^{5}$ times smaller than the mass of an atom. A more plausible explanation of the ECPs effect on the evolution of defects in metals and alloys (apart from Joule heat) must present a mechanism of accumulation of the energy of many electrons by individual atoms. Since recently, possible effects of discrete breathers (DBs) on the physical phenomena observed in crystalline solids are actively discussed [16]. DBs are spatially localized vibrational modes that can absorb energy by portions, particularly, from a current of particles [17]. The possibility of excitation of DBs in metals and alloys has been demonstrated in a number of molecular dynamics studies [18-24]. The discovery of DBs in theoretical works awakens the interest of researchers to the effect of ECPs on the structure evolution in metals and alloys.

Other studies dealt with the thermal effect of current, i.e., assumed that the parameters of current are significant enough to cause an increase of temperature in the zone of ECP processing. In our earlier works [7-13], the observed microstructural changes during ECP were suggested to be solely due to the Joule heating. Indeed, ECP provides very rapid heating. The duration of the heating is approximately equal to that of the electrical pulse, i.e. about $10^{-4} \mathrm{~s}$. On the other hand, the cooling of the pulsed material back to room temperature is not as quick as heating. Hence, the cooling stage can play an equal, if not more important, role in the microstructure evolution $[12,13]$. Despite these previous studies, many important aspects of microstructure evolution during ECP are still unclear. Also, still it remains unclear, what makes the main contribution to the structural changes taking place in the material, Joule heating or "electron wind".

As an extension of the previous research, the present study is aimed to determine the effect of Joule heating induced by electric-current pulses on the evolution of grain structure depending on the initial temperature in the specimens of copper.

\section{Material and experimental procedures}

The material used in the present work consisted of 99.9 wt. \% pure copper. The annealed material rolled at room temperature to $90 \%$ overall thickness reduction. The total thickness reduction was achieved using multiple passes. ECP was performed on plane specimens (Fig. 1). The configuration ensured the maximum heating of the central zone (with a length of $3 \mathrm{~mm}$ ), in which structural changes were observed. Specimens were cut along the rolling direction. Due to the relatively small thickness $(0.45 \mathrm{~mm})$, the skin effect was negligible.

The change in the temperature of the specimen can be determined by the equation [5]:

$$
\frac{j^{2}}{\sigma_{e}}=\rho c \frac{\partial T}{\partial t}
$$

where $\rho, c, \sigma_{e}$ is the density, heat capacity and electroconductivity of copper and $j$ is the current density.

Integrating equation (1), one obtains $S\left(T_{c}\right)=K_{j}$, where $K_{j}=\int_{0}^{\tau} j^{2} d t, S(T)=\int_{T_{1}}^{T_{2}} \rho c \sigma_{e} d T,\left(\tau\right.$ is the duration of ECP, $T_{1}$ is the initial temperature of the specimen, $T_{2}$ is the temperature attained in the specimen).

It can be seen that the current integral depends on the initial and final temperatures. Therefore, with known dependencies of density, heat capacity and electroconductivity of the material on temperature one can determine the calculated temperature of material at ECP. The relationships between the integral current density and calculated temperature for initial temperature of the specimens $-170^{\circ} \mathrm{C}$ and $20^{\circ} \mathrm{C}$ are shown in Fig. 2.

ECP was performed under room conditions by attaching copper electrodes to the end of each specimen and the subsequent discharge of a high-voltage capacitor bank.

The waveform of the ECP was determined to be a damped oscillation using a Rogowski loop and C8-17 dual-trace storage oscilloscope. The energy released during ECP was quantified by the integral current density, $K_{j}[5]$ :

$$
K_{j}=\int_{0}^{\tau} j^{2} \partial \tau=\frac{k^{2}}{S^{2}} \cdot \frac{A_{1}^{3}}{A_{2}} \cdot \frac{\tau}{4 \ln \left(\frac{A_{1}}{A_{3}}\right)}
$$

in which $j$ denotes the current density, $\tau$ is pulse duration, $k$ is the coefficient of the Rogowski coil $(k=44), S$ is crosssectional area of the pulsed specimen, and $A_{1}, A_{2}$ and $A_{3}$ are the first, second, and third amplitudes of the damped current, respectively. 


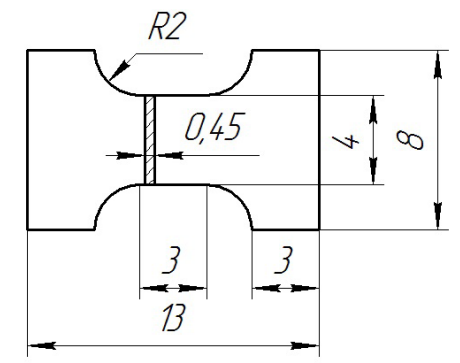

Fig. 1. The shape of specimens for the ECP.

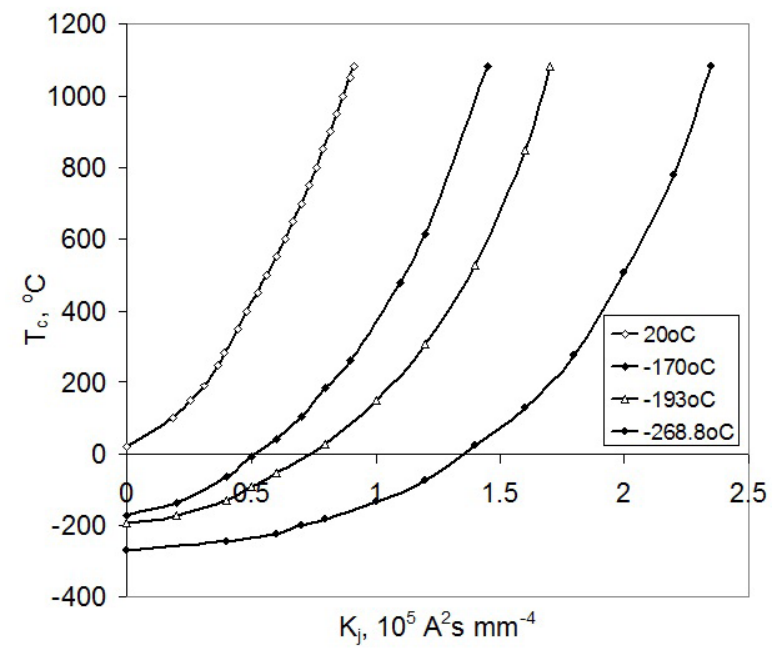

Fig. 2. The dependencies of the calculated temperature on the integral density of electric current. The dependencies at $-193^{\circ} \mathrm{C}$ and $-268.8^{\circ} \mathrm{C}$ were designed from the data of [5].

To establish the effect of ECP energy on microstructure evolution, the integral current density was varied from $K_{j}=0.384 \times 10^{5} \mathrm{~A}^{2} \mathrm{~s} \mathrm{~mm}^{-4}$ to $K_{j}=1.265 \times 10^{5} \mathrm{~A}^{2} \mathrm{~s} \mathrm{~mm}^{-4}$. The pulse duration was $100 \mu$ s in all cases.

In the present work, the calculated temperature of specimens at ECP varied from $\approx 120^{\circ} \mathrm{C}$ to $\approx 980^{\circ} \mathrm{C}$.

ECP was carried out at two initial temperatures of the specimens: $20^{\circ} \mathrm{C}$ and $-170^{\circ} \mathrm{C}$, the latter was achieved by cooling with liquid nitrogen.

For a comparison purpose static annealing of copper specimens was conducted over the temperature range $100-500^{\circ} \mathrm{C}$ for $30 \mathrm{~min}$.

Specimens for microstructural observations were prepared using conventional metallographic techniques followed by electropolishing in a solution of $70 \%$ orthophosphoric acid in water at room temperature with an applied potential of 10 $\mathrm{V}$ [12].

Microstructure analysis was conducted using a «TESCAN MIRA 3LMH» field-emission gun scanning-electron microscope equipped with a CHANNEL 5 EBSD system. To find the average grain size about 100 grains were measured in all cases. This resulted in an error of $15 \%$.

The Vickers microhardness was measured on an optical microscope Axiovert-100A with MHT-10 attachment using a load of $0.50 \mathrm{~N}$ for $10 \mathrm{~s}$. At least ten measurements were carried out for each state, while the coefficient of variation of the measurements did not exceed $5 \%$.

\section{Results and discussions}

The average grain size as a function of the integrated current density and corresponding calculated temperature of ECPs at different initial temperatures of the specimens is shown in Fig. 3. Evidently, for the recrystallization of the structure in specimens cooled with liquid nitrogen to a temperature of $-170^{\circ} \mathrm{C}$, a larger current energy is required. In our case, almost twice of the integral current density was required. However, the calculation of the temperature from the curves in Fig. 2 shows that the change in the average grain size occurs in the same temperature range in both cases. This is clearly seen from Fig. 3b, i.e. from the graph presenting the average grain size as a function of temperature.

Thus, one can see that ECP results in heating of the specimens, which leads to recrystallization in the treatment zone. As is known [25], the temperature of the recrystallization beginning depends on initial conditions. With ECP treatments, the temperature of the structural changes shifts towards higher values. For concrete conditions of the deformed state and the action of the current pulse, the temperature of the recrystallization beginning can vary within a certain temperature range. In this study in specimens of room temperature the formation of new grains begins after the ECP with $K_{j} 0.409 \mathrm{~A}^{2} \mathrm{~s} \mathrm{~mm}^{-4}$, which corresponded to a calculated temperature of $320^{\circ} \mathrm{C}$. To start recrystallization in specimens cooled with liquid nitrogen, an energy of $0.965 \mathrm{~A}^{2} \mathrm{~s} \mathrm{~mm}^{-4}$ was required, also corresponding to $320^{\circ} \mathrm{C}$. In annealed specimens the formation of new grains begins at the temperature of annealing $200^{\circ} \mathrm{C}$.

The microstructures formed after ECP treatments with energies corresponding to heating up to $370^{\circ} \mathrm{C}$ from the two initial temperatures are shown in Fig. $4 \mathrm{a}, \mathrm{b}$. Under these conditions, the microstructure formed in the treated zone is characterized by an average grain size of about $5 \mu \mathrm{m}$. For a comparison purpose, the microstructure of a specimen statically-annealed at $300^{\circ} \mathrm{C}$ for $30 \mathrm{~min}$ is given in Fig. $4 \mathrm{c}$.

It is seen that the microstructures of the specimens after ECP are similar to that of the statically recrystallized material. In view of the similarity in microstructures, one can assume that the recrystallization mechanism was nearly the same in all cases.

ECP provides very rapid heating. The duration of the heating is approximately equal to that of the electrical pulse, i.e., $10^{-4} \mathrm{~s}$. On the other hand, the cooling of the pulsed material back to room temperature is not as quick. Hence, the cooling stage may play an equal, if not more important, role in microstructure formation. The cooling time from the peak temperature to the room temperature consists $\approx 1 \mathrm{~s}$, the exact value depending on the pulsing conditions [13]. In general, the cooling time was 4 orders of magnitude greater than the pulse duration itself. It is apparent that the cooling period following ECP was thus long enough to produce a fully recrystallized structure.

The microhardness dependencies on the integrated current density and the corresponding calculated temperature of the ECP at different initial temperatures of the specimens are shown in Fig. 5. Recrystallization developed in ECP specimens leads to measurable softening in both 


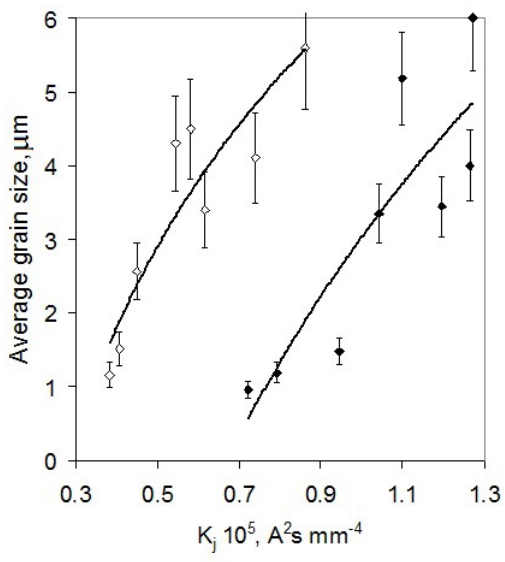

a

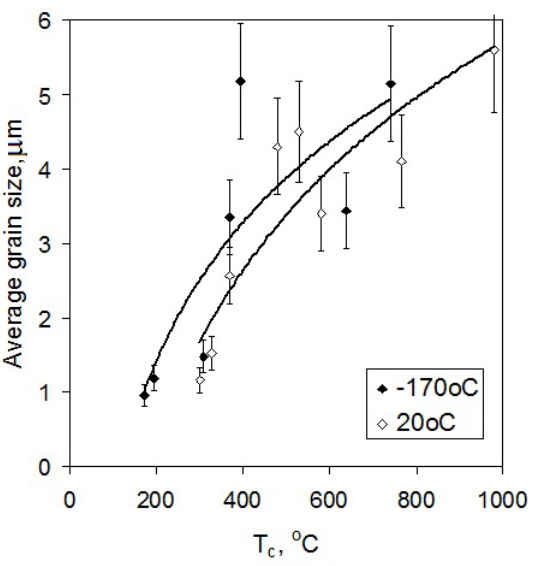

b

Fig. 3. The average grain size dependence on the integral current density (a) and on the corresponding calculated temperature (b).

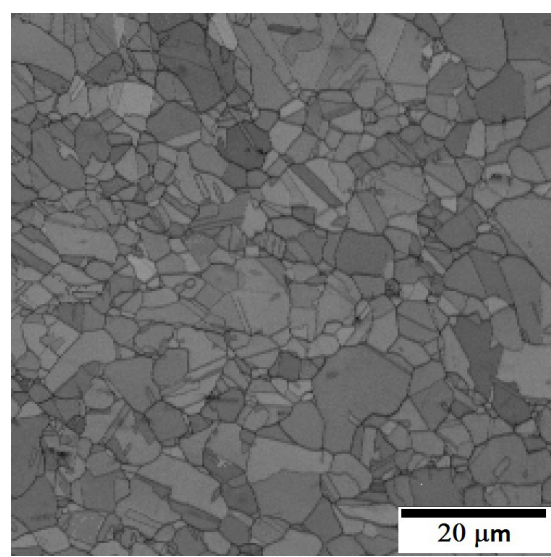

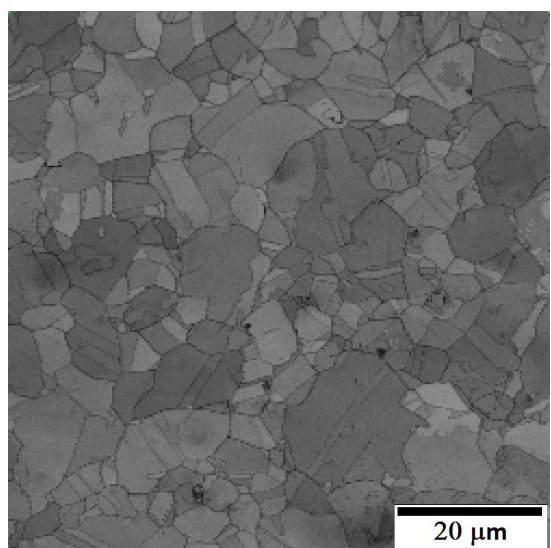

$\mathrm{b}$

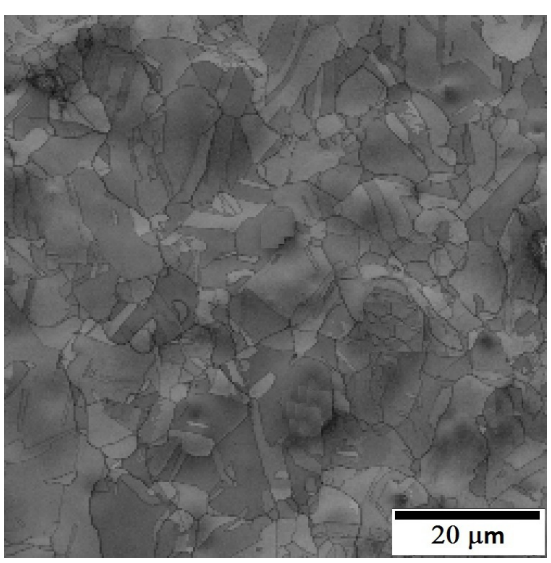

Fig. 4. The microstructure after ECP at initial temperature $20^{\circ} \mathrm{C}, K_{\mathrm{f}}=0.449 \times 10^{5} \mathrm{~A}^{2} \mathrm{~s} \mathrm{~mm}^{-4}$, calculated temperature $\approx 370^{\circ} \mathrm{C}(\mathrm{a})$; at initial temperature $-170^{\circ} \mathrm{C}, K_{j}=1.043 \times 10^{5} \mathrm{~A}^{2} \mathrm{~s} \mathrm{~mm}^{-4}$, calculated temperature $\approx 370^{\circ} \mathrm{C}(\mathrm{b})$, after static annealing $300^{\circ} \mathrm{C}, 30 \mathrm{~min}(\mathrm{c})$.

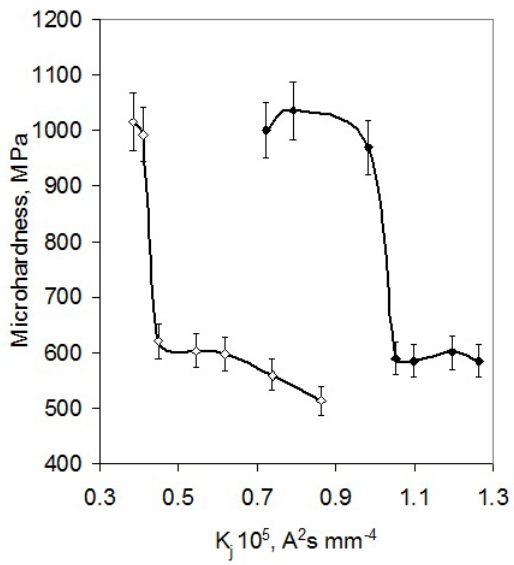

a

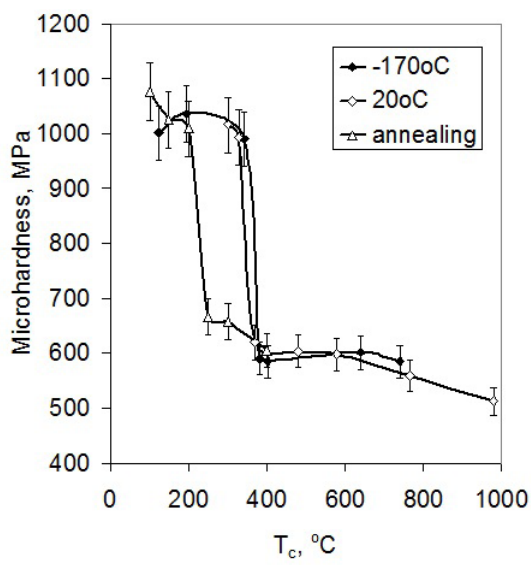

b

Fig. 5. The microhardness dependence on the integral current density (a) and on the corresponding calculated temperature (b).

cases. It can be seen that the decrease in the microhardness in specimens with an initial temperature of $-170^{\circ} \mathrm{C}$ occurs at a current density almost twice higher than in specimens with a room initial temperature. However, the calculation of the temperature from the curves in Fig. 2, as in the case with the grain size, shows that changes in the microhardness occur in the same temperature range in both cases. This is clearly seen from Fig. 5b, i.e. from the graph presenting the microhardness as a function of temperature. After reaching the calculated temperature of $\approx 370^{\circ} \mathrm{C}$, an increase in the energy input does not lead to a noticeable change in microhardness in both cases. As one can see from Fig. 5b, the microhardness of statically annealed specimens also sharply decreases at annealing temperatures above approximately $200^{\circ} \mathrm{C}$. At 
annealing temperatures above $250^{\circ} \mathrm{C}$, microhardness is stabilized, having attained the smallest value.

These results allow one to assume that the ECP, like the usual static annealing, initiates recrystallization processes. In spite of the qualitative similarity of static recrystallization and recrystallization at ECP significant difference exists between them. If thermal recrystallization takes place in the range $200-300^{\circ} \mathrm{C}$, then recrystallization at ECP occurs at the calculated temperatures $300-400^{\circ} \mathrm{C}$ in both cases. This is not surprising since it is known that even a comparatively small increase in the velocity of heating increased the temperature of recrystallization beginning significantly. In case of highvelocity heating at ECP, recrystallization results in formation of a more fine-grained structure that is attributed to formation of a larger number of centers of recrystallization.

\section{Conclusions}

The main conclusion from this work is that significant structural changes occur in the treatment zone of cold rolled copper specimens subjected to electric current pulses. As the integral current densities $0.449 \times 10^{5} \mathrm{~A}^{2} \mathrm{~s} \mathrm{~mm}^{-4}$ for initial room temperature and $1.043 \times 10^{5} \mathrm{~A}^{2} \mathrm{~s} \mathrm{~mm}^{-4}$ for initial temperature $-170^{\circ} \mathrm{C}$ are attained, the material is recrystallized completely. The microstructural changes can be explained in terms of Joule heating and are similar to those observed after static recrystallization. This similarity allows one to assume that the recrystallization mechanism during electric current treatment is similar to that operating during the conventional static annealing.

Acknowledgements. The present work was supported by the State Assignment of IMSP RAS (Reg.No AAAA-A17-117041310218-5) This research was carried out on the basis of the IMSP RAS collective use center "Structural and physical-mechanical materials research".

\section{Referencies}

1. H. Conrad, N. Karam, S. Mannan. Scr. Metall. 17, 411 (1983).

2. H. Conrad, N. Karam, S. Mannan. Scr. Metall. 18, 275 (1984).

3. H. Conrad, N. Karam, S. Mannan, A. F. Sprecher. Scr. Metall. 22, 235 (1988).

4. H. Conrad, A. F. Sprecher, W.D. Cao, X.P. Lu. JOM 42, 28 (1990).

5. H. Knoepfel. Pulsed High Magnetic Fields. NorthHolland Publishing Company, Amsterdam. (1970) 392.

6. Yu.V. Baranov, O.A. Troitsky, Yu.S. Avramov, A.D. Shlyapin. Physical principles of electropulse and electroplastic treatments and new materials. Moscow, MSIU. (2001) 844 p. (in Russian) [Баранов Ю.В., Троицкий О.А., Аврамов Ю.С., Шляпин А.Д. Физические основы электроимпульсной и электропластической обработок и новые материалы. Москва. МГИУ. (2001) 844 с.].

7. I. Sh. Valeev, Z. G. Kamalov. J. Mater. Eng. Perform. 12, 272 (2003).

8. I. Sh. Valeev, N.P. Barykin, V. G. Trifonov, Z. G. Kamalov,
A. Kh. Valeeva. Phys. Met. Metallogr. 96, 426 (2003).

9. I. Sh. Valeev, N. P. Barykin, V. G. Trifonov, A. Kh. Valeeva. J. Mater. Eng. Perform. 14, 236 (2005).

10. I. Sh. Valeev. Lett. on mater. 3 (3), 236 (2013) (in Russian) [И.Ш. Валеев. Письма о материалах. 3 (3), 236 (2013)]. DOI: $10.22226 / 2410-3535-2013-3-236-238$

11. E. V. Avtokratova, R. R. Ilyasov, I. S. Valeev, O. S. Sitdikov, M. V. Markushev. Lett. on mater. 1 (4), 194 (2011) (in Russian) [Е. В. Автократова, Р. Р. Ильясов, И.Ш. Валеев, О.Ш. Ситдиков, М.В. Маркушев. Письма о материалах 1 (4), 194 (2011) 2011. DOI: 10.22226/2410-3535-20 11-4-194-197

12. T. Konkova, S. Mironov, A. Korznikov, V. Myshlyaev, S. Lee Semiatin. J. Mater. Res. 29, 2727 (2014). DOI: 10.1557/jmr.2014.299

13. I.Sh. Valeev, A.Kh. Valeeva, A.Kh. Akhunova. Basic Probl.of Mat. Sci. 12 (2), 214 (2015) (in Russian) [И.Ш. Валеев, А.Х. Валеева, А.Х. Ахунова. Фунд. пробл. совр. материаловед. 12 (2), 214 (2015)].

14. W. Jin, J. Fan, H. Zhang, Y. Liu, H. Dong, B. Xu. J. Alloy. Compd.646, 1 (2015).DOI: 10.1016/j.jallcom.2015.04.196

15. A. Rahnama, R. Qin, Sci. Rep. 7, 42732 (2017). DOI: $10.1038 /$ srep 42732

16. S. V. Dmitriev, E.A. Korznikova, Y.A. Baimova, M. G. Velarde. Physics-Uspekhi 59 (5), 446 (2016). DOI: 10.3367/UFNe.2016.02.037729

17. P.V. Zakharov, M.D. Starostenkov, A.M. Eremin, E. A. Korznikova, S. V. Dmitriev, Phys. Solid State 59 (2), 223 (2017). DOI: 10.1134/S1063783417020342

18. M. Haas, V. Hizhnyakov, A. Shelkan, M. Klopov, A. J. Sievers, Phys. Rev. B 84, 144303 (2011). DOI: 10.1103/PhysRevB.84.144303

19. R.T. Murzaev, A.A. Kistanov, V.I. Dubinko, D. A. Terentyev, S. V. Dmitriev, Comput. Mater. Sci. 98, 88 (2015). DOI: 10.1016/j.commatsci.2014.10.061

20. D.A. Terentyev, A.V. Dubinko, V.I. Dubinko, S. V. Dmitriev, E. E. Zhurkin, M. V. Sorokin, Mod. Simul. Mater. Sci. Eng. 23, 085007 (2015). DOI: 10.1088/09650393/23/8/085007

21. V. Hizhnyakov, A. Shelkan, M. Haas, M. Klopov, Lett. on Mater. 6 (1), 61 (2016). DOI: 10.22226/2410-3535-2016-1-61-72

22. A.A. Kistanov, A.S. Semenov, R.T. Murzaev, S. V. Dmitriev, Basic Probl. of Mat. Sci. 11 (3), 322 (2014) (in Russian) [Кистанов А.А., Семенов А.C., Мурзаев Р. Т., Дмитриев С. В. Фунд. пробл. совр. материаловед. 11 (3), 322 (2014)].

23. R. T. Murzaev, E. A. Korznikova, D. I. Bokii, S. Yu. Fomin, S. V. Dmitriev, Basic Probl. of Mat. Sci. 12 (3), 324 (2015) (in Russian). [Мурзаев Р.Т., Корзникова Е. А., Бокий Д.И., Фомин С.Ю., Дмитриев С.В. Фунд. пробл. совр. материаловед. 12 (3), 324 (2015)].

24. R. T. Murzaev, R. I. Babicheva, K. Zhou, E. A. Korznikova, S. Yu. Fomin, V.I. Dubinko, S. V. Dmitriev, Eur. Phys. J. B 89 (7), 168 (2016). DOI: 10.1140/epjb/e2016-70142-3

25. Gorelik S.S., Dobatkin S. V., Kaputkina L. M. Recrystalli zation of metals and alloys. Moscow: MISIS (2005) 432 p. (in Russian). [Горелик С. С., Добаткин С. В., Капут кина Л.М. Рекристаллизация металлов и сплавов. Москва: МИСИС (2005) 432 с.] 